\title{
FAKTOR-FAKTOR YANG MEMPENGARUHI ADOPSI MOBILE PAYMENT OVO DI SAMARINDA
}

\author{
Rosita Indrawati', Syaiful Anwar ${ }^{2}$, Rano Kartono ${ }^{3}$ \\ Master of Management, Binus Business School, Binus University \\ rosita.indrawati@binus.ac.id ${ }^{1}$,syaiful.anwar@binus.ac.id², \\ rano.kartono@binus.ac.id ${ }^{3}$
}

\begin{abstract}
ABSTRAK
Perkembangan teknologi mengubah tingkah laku konsumtif masyarakat Indonesia mempengaruhi penerimaan, kepuasan atas inovasi terbaru dari pembayaran secara non-tunai (mobile payment/wallet). Penggunaan aplikasi (mobile/wallet payment) di Indonesia masih dikatakan baru hadir, menimbulkan penerimaan dan kepuasan yang beragam oleh pengguna. Tujuan dari penelitian ini adalah untuk mengetahui hubungan feature, trust, satisfaction dan loyalty terhadap penggunaan mobile payment OVO di Samarinda. Metode kuantitatif pun dipilih Peneliti untuk menyelesaikan permasalahan ini dimana teknik sampling yang digunakan Peneliti menggunakan Non Prabability Sampling dengan teknik Convenience Sampling, dimana Peneliti melakukan penyebaran kuesioner sebanyak 315 responden. Namun, kuesioner yang kembali sebanyak 198 responden. Sedangkan kuesioner yang dapat digunakan dan diteliti adalah sebesar 174 responden dan 24 responden tidak dapat kami teliti karena kuesioner tidak diisi dengan lengkap, jumlah responden tersebut sudah memenuhi jumlah ukuran sampel. Durasi sampling dalam penelitian ini selama Tiga Minggu setelah itu dilakukan analisa data statistik menggunakan Software Statistik. Hipotesis diuji menggunakan metode regresi linier yang menunjukkan bahwa sebesar $0.02 \%$ penduduk Samarinda yang didominasi oleh generasi $\mathrm{Y}$ telah menggunakan mobile payment. Faktor-faktor yang menjadi variabel pada penelitian ini yaitu layanan (feature), kepercayaan (trust), kepuasan (satisfaction), dan loyalitas (loyalty) bagi masyarakat Samarinda untuk membuat keputusan menggunakan mobile payment, menunjukkan pengaruh yang positif dan signifikan. Peneliti melihat kota Samarinda memiliki peluang yang sangat besar atas perkembangan penggunaan mobile payment.
\end{abstract}

Kata Kunci : Tekfin, Pembayaran Selular, Layanan, Kepercayaan, Kepuasan, dan Loyalitas

\section{ABSTRACK}

Technological developments change the consumptive behavior of the Indonesian people affect the acceptance, satisfaction of the latest innovations in non-cash payments (mobile payment / wallet). The use of an application (mobile / wallet payment) in Indonesia is still said to be new, gives rise to diverse acceptance and satisfaction by users. The purpose of this study is to determine the relationship of features, trust, satisfaction and loyalty to the use of OVO mobile payments in Samarinda. The researcher choosed the quantitative method this problem where the sampling technique used by the researcher used Non Prabability Sampling with the Side Convenience technique, where the researcher carried out 315 questionnaires. However, the questionnaire returned as many as 198 respondents. While the questionnaire that can be used and examined is 174 respondents and 24 respondents cannot be studied because the questionnaire is not filled in completely, the number of respondents has met the sample size. The duration of sampling in this study was three weeks after statistical data analysis was performed using Statistic Software. The hypothesis was tested using a linear regression method, which showed that $0.02 \%$ of Samarinda's population dominated by generation $Y$ had used mobile payment. The factors that become variables in this study are features, trust, satisfaction, and loyalty for the Samarinda community to make decisions using mobile payment, showing a positive and significant effect. Researchers see the city of Samarinda has a huge opportunity for the development of the use of mobile payments.

Keywords: Fintech, Mobile Payment, Feature, Trust, Satisfaction, and Loyalty 


\section{PENDAHULUAN}

Indonesia memiliki tingkat populasi yang tidak memiliki rekening bank cukup tinggi, pada tahun 2014 jumlah masyarakat Indonesia yang tidak memiliki rekening bank mencapai 95 Juta, terbesar keempat didunia setelah Cina, India dan Pakistan (Kunt, 2017). Indonesia memiliki cakupan wilayah yang luas sehingga menyebabkan penyebaran tidak merata kepemilikian rekening. Begitupula dengan masyarakat yang tinggal jauh dari tengah kota. Kesadaran masyarakat di daerah dalam hal ini kota Samarinda dalam kepemilikan rekening yang cenderung masih rendah dan penerimaan regulasi sistem perbankan yang rendah, tidak adanya dokumen identitas yang lengkap serta tingkat penghasilan masyarakat di daerah belum memadai untuk dapat menabung. Daerah Samarinda merupakan ibukota provinsi Kalimantan Timur dan merupakan kota terbesar di Pulau Kalimantan dengan jumlah penduduk 812,597 jiwa (BPS, 2016), dengan jumlah pertumbuhan penduduk yang cukup besar dari tahun 2016 ke tahun 2017 mencapai 1,8 \% (BPS Kota Samarinda, 2018). Selain itu kota samarinda pada tahun 2017 mengalami pertumbuhan ekonomi yang positif, hal ini ditandai dengan pertumbuhan ekonomi PDRB (Produk domestic regional bruto) kota Samarinda yang mencapai 3,62\%, dibandingkan tahun sebelumnya yang mencapai 0,53 $\%$. Pertumbuhan lapangan usaha tertinggi pada usaha bidang informasi dan komunikasi yang mencapai 9,94\%
(BPS Kota Samarinda, 2017). Dengan jumlah pertumbuhan lapangan usaha bidang informasi dan komunikasi di Daerah kota Samarinda yang cukup tinggi, hal ini sangat potensial dalam mendukung pertumbuhan financial technology (Fintech) di daerah tersebut.

Infrastruktur perbankan melalui mobile payment yang digunakan misalnya Mbca, Sakuku, Cimbclicks, Jenius BTPN, dan produk-produk serupa. Sedangkan produk mobile payment di luar keluaran bank terdapat seperti: Doku, Gopay, Tcash, OVO, Dana, dan lain-lain. Produk tersebut mendukung masyarakat tanpa rekening untuk memiliki rekening guna bertransaksi dengan mobile payment tersebut. Berdasarkan data pengunduh produk finansial teknologi pada mobile payment, GoJek (dengan fitur GoPay di dalamnya) dengan 10 juta lebih aplikasi di download, TCash Wallet dengan 5 juta pen-download, OVO dan Doku masing-masing 1 juta pen-download. TCash merupakan aplikasi pembayaran milik perusahaan provider Telkomsel yang dibantu dengan penggunaan stiker NFC dan bawaan dari smartphone, GoPay milik perusahaan startup transportasi online terbesar di Indonesia yang merambah ke dalam bidang finansial teknologi dengan GoPay-nya, sedangkan OVO merupakan produk digital keluaran dari LippoX yang merupakan perusahaan digital milik Lippo Group. Menurut Mallat (2007), penerapan metode mobile payment tergantung pada faktor yang mempengaruhi pilihan dan keinginan konsumen untuk menggunakan teknologi terbaru dalam melakukan 
pembayaran. Dari ke-empatnya, pasar OVO mencakup semua golongan masyarakat dan wilayah, termasuk di pelosok Indonesia seperti Samarinda.

Besarnya jumlah penduduk Indonesia yang belum memiliki akses ke lembaga jasa keuangan formal (unbanked people) memacu pertumbuhan FinTech. Unbanked People adalah penduduk Indonesia yang tidak memiliki collateral (jaminan), tidak memiliki usaha dengan usia yang matang, maupun tidak memenuhi prasyarat-prasyarat kelayakan lain untuk mendapatkan pinjaman dari lembaga keuangan. Penggunaan mobile payment OVO di daerah Samarinda yang diperkirakan memberi kemudahan dalam bertransaksi, memungkinkan naiknya pembuatan rekening bank di daerah tersebut dan mengurangi unbanked people. Perkembangan perbankan mengalami pertumbuhan yang positif di Samarinda. Hal ini, ditunjukkan dengan meningkatnya kepemilikan rekening dari tahun 2011 sebesar 20\% menjadi 49\% pada tahun 2017. Mobile payment OVO juga menjadi salah satu upaya untuk meningkatkan unbanked population dimana peluang yang ada masih sangat besar. Hal ini menunjukkan terdapatnya tingkat kepercayaan (trust) penduduk Samarinda terhadap mobile payment OVO. Menurut Hoofnagle et al. (2012), pembayaran yang dilakukan melalui perangkat nirkabel seperti mobile phone dan smartphone diperkirakan memberikan lebih banyak kemudahan, mengurangi biaya untuk transaksi, dan meningkatkan keamanan pembayaran elektronik. Masalah unbanked people tidak hanya diatasi dengan maraknya FinTech di Indonesia, tetapi bisnis ini tidak dapat berkembang tanpa adanya regulator yang bisa menjamin aspek keamanan bagi konsumen.

Menurut Orotin, P., Quisenbery, W., \& Ted Sun (2014) menyatakan bahwa mobile phone payment memiliki dampak yang signifikan bagi penggunanya dan untuk pengembangan pemasaran di Uganda. Menurut Vankatest dan Davis (1996) dalam Lai, P, C,. dan Zainal, A, A., (2015) berdasarkan model TAM yang telah ditemukan, manfaat yang dirasakan dan persepsi kemudahan penggunaan ditemukan memiliki pengaruh langsung pada prilaku niat penggunaan pembayaran elektronik.

Seiring dengan pesatnya perkembangan usaha mobile payment saat ini, maka persaingan di industri ini pun semakin meningkat. Meningkatnya persaingan ini menuntut perusahaan yang bergerak dalam jasa yang serupa selalu memperhatikan kebutuhan dan keinginan serta harapan pelanggan, agar pelanggan merasakan kemudahan dalam melakukan transaksi FinTech maka faktor feature sangat penting untuk dikembangkan sebagai upaya memberikan kemudahan bagi konsumen dalam melakukan transaksi mobile payment. Menurut Tina, Y, T, C,. (2012) Perkembangan yang sangat signifikan dalam segmen perangkat mobile phone saat ini sehingga memiliki berbagai peluang dalam konteks perkembangan bisnis khususnya dalam bidang mobile commerce dan mobile customer relationship management, hal ini membuat seseorang untuk melakukan 
transaksi dimanapun ia berada selama dapat mengakses mobile phone. Fitur, layanan dan kemudahan bertransaksi yang termasuk dalam faktor Feature dan terdapat dalam teknologi mobile phone yang telah disediakan oleh perusahaan jasa mobile payment dapat menjadi motivasi seseorang dalam penggunaan mobile payment.

Perusahaan dapat dikatakan berhasil jika perusahaan dapat memenuhi kebutuhan dan keinginan konsumen dengan memuaskan atau bahkan melebihi harapan konsumennya. Untuk itu perusahaan harus mengetahui kelompok konsumen di Samarinda serta kebutuhan dan keinginan konsumen agar dapat terbentuk trust dan satisfaction konsumen terhadap penggunaan mobile payment OVO. Konsep mengenai trust dan satisfaction pelanggan saling berhubungan satu dengan yang lainnya, karena suatu trust berasal dari satisfaction. Bahkan menurut penelitian yang dilakukan oleh Jones dan Sasser (1995) "pelanggan yang benar- benar percaya adalah pelanggan yang bener - benar merasa puas." Pelanggan yang merasa puas dengan sendirinya akan merekomendasikan produk mobile payment OVO kepada konsumen lainnya, atau yang biasa disebut dengan Word of Mouth. Berdasarkan penelitian Domingos, M., dan Ergun, G., (2018) menyatakan bahwa Trust berpengaruh dan di pengaruhi oleh faktor lainnya yang menjadikan pengguna mobile phone berniat menggunakan Mobile Payment system.

Sikap loyal dari konsumen adalah hal terpenting bagi sebuah perusahaan untuk mempertahankan eksistensinya danagardapatbertahan dalam persaingan dengan menjaga konsumen yang ada dan menarik perhatian konsumen baru. Perusahaan harus memberikan tingkat pelayanan yang baik dan tenaga kerja yang berkualitas supaya memberi kesan pengalaman positif kepada konsumen dan pada akhirnya konsumen loyal dalam penggunaan mobile payment. Selanjutnya diharapkan konsumen dapat menggunakan mobile payment OVO. Hal inilah yang dijadikan alasan untuk mengangkat tema penggunaan mobile payment OVO di Samarinda yang dipengaruhi oleh feature, trust, satisfaction dan loyalty konsumen. Beberapa factor tersebut yang meliputi feature, trust, satisfaction dan loyalty dinilai berpotensi memiliki pengaruh positif terhadap penggunaan mobile payment OVO oleh masyarakat di Kota Samarinda. Adapun tujuan dari penelitian ini adalah untuk mengetahui hubungan feature, trust, satisfaction dan loyalty terhadap penggunaan mobile payment OVO di Samarinda.

\section{TEORI}

Berdasarkan penelitian kami yaitu Adopsi Finansial Teknologi Mobile Payment OVO di Samarinda, adapun variabelnya adalah feature, trust, satisfaction dan loyalty terhadap penggunaan mobile payment OVO di Samarinda.

\section{Feature}

Menurut Raina pembayaran seluler adalah transaksi dengan nilai moneter yang dilakukan 
melalui jaringan telekomunikasi seluler melalui beragam perangkat pengguna seluler, seperti telepon seluler, ponsel pintar atau PDA, dan terminal seluler. Pembayaran seluler adalah mentransfer dana sebagai imbalan atas barang atau jasa di mana perangkat seluler secara fungsional terlibat dalam melaksanakan dan mengkonfirmasi pembayaran. Pelanggan dapat berdiri di Point Of Sale (POS) atau berinteraksi dengan pedagang yang berlokasi di tempat lain. Sistem pembayaran seluler memungkinkan pelanggan untuk membeli dan membayar barang atau jasa melalui ponsel. Setiap ponsel digunakan sebagai alat pembayaran pribadi sehubungan dengan penjualan jarak jauh. Pembayaran dapat dilakukan pula dari jarak jauh.

Chen (2010) menyampaikan bahwa sistem pembayaran seluler untuk pembayaran pedagang mikro yang dapat dibangun di atas komponen arsitektur GSM dan NFC yang tersedia. Penulis memanfaatkan kapabilitas otentikasi dan identifikasi SIM dan menggunakan primitif kriptografi, yang menyederhanakan integrasi ke dalam infrastruktur seluler saat ini. Penggunaan NFC untuk komunikasi jarak pendek memungkinkan mengintegrasi dengan peralatan Point Of Sale (POS) yang ada dan proses pembayaran dari perspektif pelanggan dan pedagang tetap tidak berubah. Teknologi dalam pengembangan pembayaran seluler telah meningkat dan mengalami perkembangan yang signifikan, perangkat seluler dan jaringan nirkabel masih terbatas sumber dayanya dibandingkan dengan PC dan jaringan telepon tidak bergerak. Kesulitan dalam membangun sistem mobile payment terletak pada menyediakan transaksi pembayaran dengan keamanan dan kepraktisan.

\section{Trust}

Fathi Syahrul pada penelitian "Analisis Penerimaan E-Wallet Di Indonesia: Studi Kasus Doku Wallet", penerimaan e-wallet pada produk Doku Wallet menjelaskan bahwa faktor-faktor yang mempengaruhi adopsi ewallet di Indonesia khususnya Doku adalah electronic word-of-mouth (e-WOM), trust, risiko, dan tingkat kemudahan penggunaan. Penelitian tersebut menjelaskan studi kasus mobile payment/wallet berbasis digital yaitu Doku di Indonesia dan menyimpulkan bahwa terdapat beberapa faktor adopsi ewallet seperti ewom, trust, risiko, dan kemudahan. Adapun penelitian ini menggunakan survei terhadap pengguna Doku di Indonesia. Pengguna Doku di Indonesia hampir sama dengan OVO yaitu 1 juta pengguna (berdasarkan data penginstall pada google play store dan app store), namun perbedaannya, Doku memiliki jam terbang yang lebih lama dibanding dengan OVO.

Antwi, Hamza, dan Bavoh (2015), dalam artikelnya yang berjudul "Examining the Effectiveness of Electronic Payment System in Ghana : The Case of e-ZWICH in the Tamale Metropolis", menjelaskan mengenai keefektifan dari bentuk sistem pembayaran elektronik di metropolis Tamale di Ghana. Penelitian ini menggunakan administrasi kuesioner untuk memastikan jenis umum sistem 
pembayaran elektronik, tingkat adopsi e-ZWICH, dan faktor-faktor yang mempengaruhi keefektifannya.

Berdasarkan penelitian Hoofnagle (2012), Bezhovski (2016), mobile payment/wallet terhadap privacy, trust, expectancy, akan meningkatkan keamanan dan kepercayaan, sehingga meningkatnya user mobile payment OVO di Samarinda.

\section{Satisfaction}

Kepuasan adalah tingkat perasaan dimana seseorang menyatakan hasil perbandingan atas kinerja produk atau jasa yang diterima dan yang diharapkan. Kepuasan merupakan fungsi dari presepsi atau kesan atas kinerja dan harapan, jika kinerja berada di bawah harapan pelanggan tidak puas. Jika kinerja memenuhi harapan, pelanggan puas, jika kinerja melebihi harapan, pelanggan amat puas atau senang (Kotler et al,2003). Sedangkan menurut Rangkuti $(2006,30)$, kepuasan pelanggan didefinisikan sebagai respon pelanggan terhadap ketidaksesuaian antara tingkat kepentingan sebelumnya dan kinerja aktual yang dirasakannya setelah pemakaian.

Faktor-faktor yang mempengaruhi kepuasan menurut pendapat Lupiyoadi (2001), menyebutkan ada lima faktor yang mempengaruhi kepuasan yaitu kualitas produk, kualitas pelayanan, emosional, harga dan biaya. Konsumen tidak perlu mengeluarkan biaya tambahan atau tidak perlu membuang waktu untuk mendapatkan suatu produk atau jasa, mereka akan cenderung puas terhadap produk atau jasa tersebut (Lupiyoadi,2001).
Menurut Yamit (2010,78), bahwa kepuasan pelanggan adalah hasil (output) yang dirasakan atas penggunaan produk dan jasa ataupun melebihi harapan yang diinginkan.

\section{Loyalty}

Konsep loyalitas pelanggan menurut costabile dalam Smith and Wright, (2004) adalah suatu bentuk hubungan yang kuat antara konsumen dengan perusahaan. Menurut Hill sebagaimana dikutip dalam Rusdarti (2004) loyalitas adalah perilaku yang ditunjukan dengan pembelian rutin yang didasarkan pada unit pengambilan keputusan. Selanjutnya Grifin sebagaimana dikutip dalam Smith and Wright (2004) menyatakan bahwa seorang konsumen menjadi loyal maka seorang konsumen harus melalui beberapa tahapan diantaranya suspects, prospect, disqualified prospect, first time customer, repeat customer, client, advocates.

Ada beberapa indikator dalam mengukur loyalitas pelanggan yaitu: rebuy, retention dan referral (Rusdarti, 2004). Sedangkan menurut Singh dalam Rusdarti, (2004) indikator loyalitas konsumen adalah prosentase dari pembelian, frekuensi kunjungan dan merekomendasikan kepada orang lain. Adapun indikator- indikator dalam penelitian ini diacu dari penelitian Selness (Smith dan Wright (2004), Chow dan Holden (2007) dan Musry (2004) yaitu pembelian ulang, rekomendasi, kelanjutan hubungan dan komitmen. Bloemer et.al (2008) dalam penelitiannya menekankan akan arti pentingnya pembentukan loyalitas 
sebagai dasar bagi perusahaan untuk bertahan dan menghadapi persaingan. Menurutnya loyalitas pelanggan dapat tumbuh disebabkan oleh beberapa faktor, seperti citra baik yang dimiliki, kualitas pelayanan yang diberikan dan kepuasan terhadap pelanggan. Faktorfaktor tersebut memegang peran penting dalam meningkatkan posisi persaingan .

\section{Mobile Payment}

Menurut Mallat (2007) dalam Exploring Consumer Adoption of Mobile Payments - A Qualitative Study. Helsinki Institute of Economics, penerapan metode mobile payment tergantung pada faktor yang mempengaruhi pilihan dan keinginan konsumen untuk menggunakan teknologi terbaru dalam melakukan pembayaran. Berkembangnya sebuah sistem pembayaran digital yang baru dengan aplikasi smartphone menimbulkan persepsi penerimaan baru dalam masyarakat Indonesia dan adopsi baru dalam penggunaanya yang menentukan pengembangan kedepannya. Penelitian tersebut menerangkan bagaimana penerimaan pengguna mobile payment dan finansial teknologi lainnya yang menentukan dalam pengembangan kedepannya. Hal ini berkaitan dengan penerimaan pengguna yang kemudian dapat disimpulkan potensi masa depan dalam bidang ini.

Berdasarkan studi literaur dapat diuraikan bahwa faktor yang berpontensi dapat mempengaruhi seseorang dalam menggunakan mobile payment $\mathrm{OVO}$ meliputi beberapa faktor yaitu : feature, trust, satisfaction dan loyalty.

\section{METODE PENELITIAN}

\section{Desain Penelitian}

Penelitian ini menggunakan metode penelitian dengan menggunakan metode kuantitatif survei. Survei yang dilakukan adalah pertanyaan mengenai Adopsi Finansial Teknologi Mobile Payment OVO di Samarinda. Metode penelitian ini dirancang untuk memenuhi tujuan penelitian yaitu untuk mengetahui hubungan feature, trust, satisfaction dan loyalty terhadap penggunaan mobile payment OVO di Samarinda.

\section{Populasi}

Peneliti

menentukan populasi tujuan untuk mengetahui adopsi penggunaan finansial teknologi mobile payment OVO di luar kota Jakarta, yakni kota Samarinda merupakan ibu kota provinsi Kalimantan Timur. Berdasarkan Badan Pusat Statistik Kota Samarinda, jumlah penduduk Kota Samarinda adalah 812,597 jiwa, sehingga total populasi adalah sebesar 812,597 penduduk. Menurut Gay dan Diehl (1992) mengansumsikan bahwa semakin banyak sampel yang diambil maka akan semakin representative dan hasilnya dapat digenelarisir, namun ukuran sampel yang diterima akan sangat bergantung pada jenis penelitiannya, jika penelitiannya korelasional sampel minimunya adalah 30 subjek. Menurut Roscoe (1975) ukuran sampel lebih dari 30 dan kurang dari 500 adalah tepat untuk kebanyakan penelitian. Dengan demikian peneliti melakukan penyebaran kuesioner 
sebanyak 315 responden. Namun, kuesioner yang kembali sebanyak 198 responden. Sedangkan kuesioner yang valid dapat digunakan dan diteliti adalah sebesar 174 responden dan 24 responden tidak dapat kami teliti karena kuesioner tidak diisi dengan lengkap.

\section{Proses Sampling}

Penelitian menggunakan teknik ini akan sampling di mana teknik ini merupakan turunan dari non probability sampling. Non probability sampling (Sugiyono, 2016) adalah teknik yang digunakan untuk pengambilan sampel yang tidak memberi kesempatan atau peluang yang sama bagi setiap anggota populasi atau setiap unsur untuk dipilih menjadi sebuah sampel. Sedangkan metode convenience sampling ini merupakan teknik menentukan sampling berdasarkan kebetulan saja, anggota populasi yang ditemui peneliti dan bersedia menjadi responden akan dijadikan sampling. Kami akan membagi sampling menjadi dua kelompok usia yaitu Gen Y dan Gen $\mathrm{X}$ dengan tujuan pengambilan sampling akan merata pada seluruh tingkatan dan sampling mewakili karakter seluruh elemen populasi yang heterogen. Pengguna mobile payment didominasi oleh pengguna berusia muda, maka kami membutuhkan represtasi yang berimbang untuk pengguna dengan usia yang lebih tua.

\section{Populasi kota Samarinda} adalah sebesar 812,597 penduduk dan diperoleh sampling sebesar 174 responden. Responden dikelompokkan menjadi tingkat Generasi X 15 orang
(Usia 38-58 Tahun), Generasi Y 159 orang (Usia 18 - 38 Tahun).

\section{Pengambilan Data}

Pada tahun 2019, peneliti telah melakukan survey terhadap sampling tersebut. Kuesioner terbagi menjadi 2 bagian yaitu bagian I berisi kuesioner profile responden dan bagian keII berisi sejumlah pernyataan yang disesuaikan dengan variable-variabel feature, trust, satisfaction dan loyalty. Kuesioner ini akan disampaikan kepada responden untuk diisi secara manual maupun melalui kuesioner Google Form. Kuesioner yang sah adalah kuesioner yang diisi lengkap oleh responden pengguna OVO sesuai form dan disampaikan melalui Google Form dan Form manual, serta form kuesioner harus diisi oleh nama responden yang berbeda.

\section{Metode Analisa Data}

Kuesioner berbentuk pernyataan dengan pilihan jawaban dinyatakan dengan skala Likert 5.0. Skala Likert adalah teknik pemberian skor untuk menilai sikap, pendapat, atau persepsi seseorang terhadap suatu fenomena atau keadaan (Sugiyono, 2013). Dengan skala Likert, maka variabel yang akan diukur dijabarkan menjadi indikator variabel. Kemudian indikator tersebut menjadi titik tolak untuk menyusun item-item instrumen yang dapat berupa pernyataan dan pertanyaan. Hal ini disampaikan pula oleh Keisidou (2015). Sekala likert ini meliputi: Sangat Setuju (SS) $=5$, Setuju $(\mathrm{S})=4$, Kurang Setuju $(\mathrm{KS})=$ 3 , Tidak Setuju $(T S)=2$, Sangat Tidak 
Setuju $(\mathrm{ST})=1$. Pada masing masing variable penelitian terdapat berbagai pertanyaan yang tercantum dalam kuesioner masing masing dikelompokan pada variabel bebas (independent) yaitu; Feature, Trust, Satisfaction, dan Loyalty. Variabel terikat (dependent) yaitu ; mobile payment. Masing masing kuesioner terdapat skala likert.

Setelah data terkumpul, dilakukan pengolahan dan analisa data serta pengujian hipotesis menggunakan software analisa data statistik SPSS, dimana pada penelitian ini ada empat hipotesis, yaitu :

H1: Feature berpengaruh positif terhadap penggunaan mobile payment OVO

H2: Trust berpengaruh positif terhadap penggunaan mobile payment OVO

H3: Satisfaction berpengaruh positif terhadap penggunaan mobile payment OVO

H4: Loyalty berpengaruh positif terhadap penggunaan mobile payment $\mathrm{OVO}$

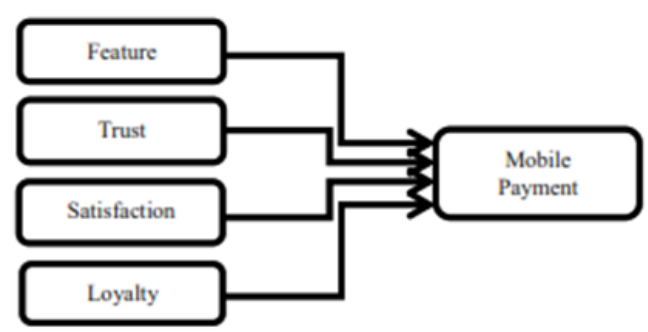

Gambar 1. Concept Model Framework

\section{PEMBAHASAN}

\section{Uji Validitas dan Reliabilitas}

Uji validitas digunakan untuk mengukur valid tidaknya suatu instrument(kuesioner). Suatu instrument (kuesioner) dikatakan valid jika pertanyaan pada instrumen (kuesioner) mampu mengungkapkan sesuatu yang akan diukur oleh instrument (kuesioner) tersebut. Uji signifikansi dilakukan dengan membandingkan nilai rhitung dengan rtabel untuk degree of freedom $(\mathrm{df})=\mathrm{n}-2$, dalam hal ini $\mathrm{n}$ adalah jumlah sampel. Untuk melihat nilai rtabel dilihat pada $\alpha=$ $0,05 \mathrm{r}$ product moment. Jika $r_{\text {hitung }}>r_{\text {tabel }}$ dan nilai positif maka item pertanyaan valid (Ghozali, 2008). Penghitungan $\mathrm{r}_{\text {hitung }}$ dilakukan menggunakan Pearson Product Moment yang dirumuskan pada Persamaan 1 (Ghozali, 2008). Terdapat 5 variable yang akan diuji yaitu Feature, Trust, Satisfaction, Loyalty dan Mobile Payment.

Tabel 1. Feature (X1) Uji Validitas

\begin{tabular}{|l|c|c|c|c|c|c|c|}
\hline & F1 & F2 & F3 & F4 & F5 & F6 & F7 \\
\hline $\begin{array}{l}\text { Corrected } \\
\text { Item- } \\
\text { Total Cor- } \\
\text { relation }\end{array}$ & 0,627 & 0,517 & 0,535 & 0,486 & 0,435 & 0,449 & 0,556 \\
\hline
\end{tabular}

Tabel 2. Trust (X2) Uji Validitas

\begin{tabular}{|l|c|c|c|c|c|c|c|}
\hline & $\mathrm{T} 1$ & $\mathrm{~T} 2$ & $\mathrm{~T} 3$ & $\mathrm{~T} 4$ & $\mathrm{~T} 5$ & $\mathrm{~T} 6$ & $\mathrm{~T} 7$ \\
\hline $\begin{array}{l}\text { Corrected } \\
\text { Item- } \\
\text { Total Cor- } \\
\text { relation }\end{array}$ & 0,625 & 0,664 & 0,601 & 0,735 & 0,744 & 0,586 & 0,673 \\
\hline
\end{tabular}

Tabel 3. Satisfaction (X3) Uji Validitas

\begin{tabular}{|l|c|c|c|c|c|c|c|}
\hline & S1 & S2 & S3 & S4 & S5 & S6 & S7 \\
\hline $\begin{array}{l}\text { Corrected } \\
\text { Item- } \\
\text { Total Cor- } \\
\text { relation }\end{array}$ & 0,639 & 0,537 & 0,582 & 0,631 & 0,66 & 0,703 & 0,681 \\
\hline
\end{tabular}


Tabel 4. Loyalty (X4) Uji Validitas

\begin{tabular}{|l|c|c|c|c|c|c|c|}
\hline & L1 & L2 & L3 & L4 & L5 & L6 & L7 \\
\hline $\begin{array}{l}\text { Corrected } \\
\begin{array}{l}\text { Item- } \\
\text { Total Cor- } \\
\text { relation }\end{array}\end{array}$ & 0,71 & 0,711 & 0,449 & 0,656 & 0,64 & 0,65 & 0,641 \\
\hline
\end{tabular}

Tabel 5. Mobile Payment (Y) Uji Validitas

\begin{tabular}{|l|c|c|c|c|c|c|c|c|}
\hline & M1 & M2 & M3 & M4 & M5 & M6 & M7 & M8 \\
\hline $\begin{array}{l}\text { Cor- } \\
\text { rected }\end{array}$ & 0,576 & 0,614 & 0,633 & 0,607 & 0,539 & 0,566 & 0,59 & 0,391 \\
$\begin{array}{l}\text { Item- } \\
\text { Total } \\
\text { Correla- } \\
\text { tion }\end{array}$ & & & & & & & & \\
\hline
\end{tabular}

Hasil perhitungan yang ditampilkan pada 5 indikator mendapat nilai $r_{\text {hitung }}>r_{\text {tabel }} 0,2199$. Sehingga dapat disimpulkan bahwa kelima indikator tersebut adalah valid.

Tabel 6. Uji Realibilitas

\begin{tabular}{|l|c|c|}
\hline \multicolumn{1}{|c|}{ Variables } & $\begin{array}{c}\text { Cronbach's } \\
\text { Alpha }\end{array}$ & N of Items \\
\hline Feature & 0,766 & 7 \\
\hline Trust & 0,871 & 7 \\
\hline Satisfaction & 0,860 & 7 \\
\hline Loyalty & 0,862 & 7 \\
\hline $\begin{array}{l}\text { Mobile } \\
\text { Payment }\end{array}$ & 0,831 & 8 \\
\hline
\end{tabular}

Dari hasil pengujian Reliabilitas pada tabel di atas dapat diketahui bahwa berdasarkan dari jawaban responden pada variable penelitian diperoleh nilai cronbach alpha lebih dari 0,6 maka terbukti reliable.

\section{Uji Hipotesa}

Hubungan yang dihipotesiskan diuji menggunakan analisis metode regresi linier dengan alat SPSS. Dalam hipotesis H1, H2, H3, H4 kami melakukan penelitian terhadap
Feature, Trust, Satisfaction dan Loyalty berpengaruh positif terhadap penggunaan Mobile Payment OVO.

Tabel 7. Tabel Annova

\begin{tabular}{|c|l|l|c|c|c|c|}
\hline & Model & $\begin{array}{c}\text { Sum of } \\
\text { Squares }\end{array}$ & df & $\begin{array}{c}\text { Mean } \\
\text { Square }\end{array}$ & F & Sig \\
\hline \multirow{2}{*}{1} & Regression & 12,171 & 4 & 3,043 & 26,181 &, $000^{\mathrm{b}}$ \\
\cline { 2 - 7 } & Residual & 8,717 & 75 & 0,116 & & \\
\cline { 2 - 7 } & Total & 20,887 & 79 & & & \\
\hline
\end{tabular}

Berdasarkan hasil uji statistik diatas dapat diketahui bahwa nilai signifikansi atau p-value $<0,05$ sehingga secara simultan variabel X1, $\mathrm{X} 2$, X3 dan X4 berpengaruh signifikan terhadap $\mathrm{Y}$.

Tabel 8. Ringkasan Model

\begin{tabular}{|c|c|c|c|}
\hline $\mathrm{R}$ & $\begin{array}{c}\mathrm{R} \\
\text { Square }\end{array}$ & $\begin{array}{c}\text { Adjusted } \\
\text { R Square }\end{array}$ & $\begin{array}{c}\text { Std Error } \\
\text { of the } \\
\text { Estimate }\end{array}$ \\
\hline 0,763 & 0,583 & 0,56 & 0,34091 \\
\hline
\end{tabular}

Dari perhitungan di atas diketahui bahwa nilai koefisien korelasi berganda (R), yaitu korelasi antara dua atau lebih variabel X1, X2, X3, dan X4 terhadap variabel Y sebesar 0,763. Hal ini berarti terdapat hubungan yang sangat kuat. Nilai koefisien determinasi berganda ( $\mathrm{R}$ Square) adalah 0,583 atau 58,3\% yang berarti nilai ini menunjukkan bahwa sebesar 58,3\% variabel $\mathrm{Y}$ dipengaruhi $\mathrm{X} 1, \mathrm{X} 2$, $\mathrm{X} 3$ dan X4 sedangkan sisanya 41,7\% dipengaruhi oleh variabel lain diluar penelitian.

Pada penelitian ini membuktikan pernyataan Chen (2010) yaitu bahwa sistem pembayaran seluler untuk pembayaran pedagang mikro 
dibangun di atas komponen arsitektur GSM dan NFC yang tersedia. Di mana masyarakat Samarinda, menggunakan pembayaran seluler dibandingkan dengan PC. Serta ditemukan bahwa pengguna OVO area kota Samarinda dimana penggunaan mobile payment OVO dipengaruhi signifikan karena ada infrastruktur dalam hal ini fitur, layanan, marchant yang disediakan dan bekerjasama dengan OVO. Hal ini dibuktikan dengan $100 \%$ dari responden menggunakan telepon selular untuk melakukan transaksi dan dikuatkan dengan hasil penelitian kami dimana Feature berpengaruh positif terhadap penggunaan mobile payment OVO.

Masyarakat Samarinda pun berantusias dan mulai membangkitkan kepercayaan (trust) terhadap metode pembayaran OVO ini. Penelitian kami pun sejalan dengan hasil penelitian Syahrul (2014) mengenai "Analisis Penerimaan E-Wallet Di Indonesia: Studi Kasus Doku Wallet", menyatakan bahwa tingkat kepercayaan (trust) merupakan salah satu faktor masyarakat untuk menggunakan mobile payment OVO.

Adapun menurut Yamit (2010, 78), bahwa kepuasan (satisfaction) pelanggan adalah hasil (output) yang dirasakan atas penggunaan produk dan jasa ataupun melebihi harapan yang diinginkan. Satisfaction terhadap mobile payment $\mathrm{OVO}$, dirasakan benar oleh kelompok generasi $\mathrm{Y}$ yang masih berada pada usia sekolah dan memiliki pendapatan $\leq \mathrm{Rp} 24.000 .000 /$ tahun.

Penelitian kami pun membuktikan pernyataan Hill yang dikutip dalam
Rusdarti (2004) loyalitas adalah perilaku yang ditunjukan dengan pembelian rutin yang didasarkan pada unit pengambilan keputusan, di mana masyarakat Samarinda menggunakan mobile payment OVO untuk melakukan segala transaksi guna mempermudah kebutuhannya dan menghemat waktu.

Temuan penelitian ini memberikan dukungan terhadap penelitian Keisifdou (2015) sebelumnya yang menyatakan bahwa customer satisfaction merupakan faktor yang paling berpengaruh terhadap customer loyalty. Hal ini pun dibuktikan dalam penelitian ini yaitu Satisfaction dan Loyalty berpengaruh positif terhadap penggunaan mobile payment.

\section{Pembahasan}

Penelitian ini telah dilakukan pengambilan sampel pada responden yang merupakan pengguna mobile payment OVO dan merupakan masyarakat Samarinda di berbagai usia yang dianggap mewakili populasi masyarakat Samarinda dengan rentang umur 17 s.d 53 tahun dengan presentasi responden $45 \%$ responden berjenis kelamin laki-laki dan $55 \%$ responden berjenis kelamin perempuan dengan system penyebaran kuesioner melalui penyebaran secara online dan manual (Angket Wawancara). Penelitian ini menggunakan teknik non probability sampling dengan cara convenience sampling. Metode ini merupakan teknik menentukan sampling berdasarkan kebetulan saja, anggota populasi yang ditemui peneliti dan bersedia menjadi responden akan dijadikan sampling. Adapun metode analisa data pada penelitian ini menggunakan Statistical 
Product and Service Solutions (SPSS) untuk menguji model structural yang di kembangkan berdasarkan kajian literatur.

Pada penelitian ini mengidentifikasi untuk melakukan evaluasi terhadap model yang dikembangkan, penelitian ini menggunakan software SPSS yang diperoleh secara legal. Untuk melakukan validasi dalam penelitian ini, maka peneliti menentukan variabel yang diukur mendekati pernyataan Mallat (2007) dalam Exploring Consumer Adoption of Mobile Payments - A Qualitative Study. Helsinki Institute of Economics, dimana penerapan metode mobile payment tergantung pada faktor yang mempengaruhi pilihan dan keinginan konsumen untuk menggunakan teknologi terbaru dalam melakukan pembayaran. Untuk melakukan pengujian pada model penelitian ini, peneliti mengembangkan kuesioner yang kemudian didistribusikan kepada responden. Responden pada penelitian ini masyarakat Kota Samarinda. sejumlah 174 responden berpartisipasi pada penelitian ini.

Kelompok responden variatif dari kelompok usia remaja, dewasa dan orang tua, dengan rata rata usia 17-21 tahun yang memiliki kecenderungan merupakan Gen Y atau generasi millennial yang memiliki kecenderungan lebih tinggi untuk mengadopsi inovasi dibandingkan usia yang lebih tinggi. Kelompok usia yang variatif ini diharapkan memberikan kontribusi akurasi data yang akan dilakukan analisa pada penelitian ini. 


\section{KESIMPULAN}

Penelitian kami adalah kumpulan jawaban dari responden untuk menganalisa faktor-faktor yang mempengaruhi adopsi Mobile Payment OVO di Samarinda. Sebesar $0.02 \%$ penduduk Samarinda telah menggunakan mobile payment OVO. Jumlah tersebut dikatakan baik untuk skala kota Samarinda yang tidak berpenduduk banyak dan bukan merupakan daerah Ibukota Negara. Generasi Y mendominasi penggunaan mobile payment $\mathrm{OVO}$ di kota Samarinda karena salah satu keunggulannya adalah mobile payment OVO banyak memberikan penawaran yang sangat menarik. Faktor-faktoryangmendorong masyarakat Samarinda untuk membuat keputusan menggunakan mobile payment OVO, kami menemukan layanan (feature), kepercayaan (trust), kepuasan (satisfaction), dan loyalitas (loyalty) memiliki pengaruh yang positif dan signifikan.

Penelitian ini memberikan implikasi teoritis dan manajerial. Dari segi teoritis, penelitian ini memberikan implikasi bahwa mobile payment OVO harus mempertimbangkan dampak secara lebih cermat bagi para pengguna generasi Y. Hal ini dikarenakan para pengguna pada usia tersebut cenderung menggunakan mobile payment $\mathrm{OVO}$ sedangkan penelitian ini menggunakan responden dengan usia bervariatif. Strategi yang perlu dilakukan oleh mobile payment OVO adalah memberikan edukasi kepada pengguna berusia tua agar mereka lebih familiar, dan pada akhirnya akan menggunakan teknologi mobile payment.

Satisfaction dan Loyalty telah banyak digunakan untuk mengamati tingkat penerimaan teknologi atau produk baru. Penelitian ini sekali lagi membuktikan bahwa customer satisfaction merupakan faktor yang paling berpengaruh terhadap . Hal ini diindikasikah oleh seluruh hipotesis yang dilakukan dalam penelitian ini diterima. Variabel-variabel lain yang dapat ditambahkan ke dalam penelitianpenelitian berikutnya diantaranya adalah budaya, gaya hidup pengguna teknologi baru.

\section{SARAN}

Dari hasil penelitian ini kami berharap dapat memberikan manfaat dan masukan bagi mobile payment OVO atau Finansial Teknologi lain yang sudah ada maupun baru untuk memperkuat feature dan loyalty dengan cara meningkatkan strategi pemasaran ataupun strategi lainnya di kota Samarinda mengingat potensi yang sangat besar untuk menambah jumlah pengguna mobile payment OVO. Generasi Y yang paham akan teknologi pun memiliki potensi untuk membantu mengembangkan mobile payment OVO.

\section{DAFTAR PUSTAKA}

Abrazhevich, D. (2004). Electronic PaymentSystems:aUser-Centered Perspective and Interaction Design. Netherlands: Technische Universiteit Eindhoven.

Adelman, D. (2015). Actor-based 
incentives for the restriction of mobile payments in developing countries. Social Impact Research Experience (SIRE).

Bolibok P. \& Zukowski M. (2015), The impact of inequalities in regional economic development on disparities in spatial distribution of cashless payment infrastructure in Poland, Journal of Economics and Management. Vol. 21 (3)

Bank Indonesia. Digital Final Inclusion in Indonesia.

Bloemer, J.,Ko de Ruyter, \& Pascar Peeters. (2008). Investigating Drivers of Bank Loyalty : the Complex Relationship Between Image, Service Quality, and Satisfaction. International Journal of Bank Marketing, Vol.17,No.7.

BPS Kota Samarinda Tahun 2017

BPS Kota Samarinda Tahun 2018

Chen, J.J. \& Adams, C. (2005). User acceptance of mobile payments: a theoritical model for mobile payments. In 5th International Conference on elecronic Business, Hong Kong, December (pp.5-9)

Coulter, et.al. (2005). The Evolution of Consumer Knowledge and Sources of Information: Hungary in Transition. Journal of the Academy of Marketing Science.

Demirguc, K, A. 2017. The Global Findex Database 2017 : Measuring Financial Inclusion and the Fintech Revolution. Retrieved from http://documents. worldbank.org/

Diaz, J. N., Ledesma, J., Anjana, R., Singh, J., \& Tyler, E. (2011). Saving for the Poor In the
Philippines. The New American Foundation and MicroSave.

Doan, N. (2014). Consumer adoption in Mobile Wallet. The Turku University of Applied Sciences.

Faering M. (2013), Beyond loyalty: customer satisfaction, loyalty, and fortitude. International Journal of Bank Marketing

Fathi, S. (2014). Analisis Penerimaan E-Wallet di Indonesia:Studi Kasus Doku Wallet. Retrieved from http://www.bibme.org/ citation-guide/apa/ book/

Fadlillah, Ferry F. (2018). Sudah Saatnya Beralih ke E-money, Alat Pembayaran Zaman Now. Retrieved fromhttps:// www.kemenkeu.go.id/publ ikasi/artikel-dan-opini/sudahsaatnya-b eralih-ke-e-money-alatpembayaran-za man-now/

Ghozali, I. (2008). Generalized Structured Component Analysis (GSCA): Model Persamaan Struktural Berbasis Komponen. Semarang: Badan Penerbit Universitas Diponegoro

Guild, J. (2017). Fintech and the Future of Finance. Asian Journal of Public Affairs.

Hidayat, A. (2017, December 16). Cara Hitung Rumus Slovin. Retrieved from https://www. statistikian.com/2017/12/hitungrumus-slovin-sampel.htm 1

Hoofnagle, Chris J., Urban, Jennifer M. and Su Li. (2012). Mobile Payments: Consumer benefits and new privacy concerns. BCLT Research Paper. 
Hogarth, J. M., \& O'Donnell, K. H. (1999). Banking Relationships of Lower-Income Familes and Governmental Trend toward Electronic Payment. Federal Reserve Bulletin, 85, 459-473.

Hogarth, J. M., Anguelov, C. E., \&

Lee, J. (2003). Why Households

Don't Have Checking Accounts.

Economic Development

Quarterly, 17 (1), 75-93.

Hogarth, J. M., Anguelov, C. E., \& Lee, J. (2005). Who Has a Bank Account? Exploring Changes Over Time, 1989-2001. Journal of Family and Economic Issues, 26 (1), 7-30.

Kendall, J. (2010). Improving People's Lives Through Savings. Scholarly Report.

Jones, T.O. and W.E. Sasser, Jr. (1995).

Why Satisfied Customer Defect. Harvard Business Review, Nopember-December. Retriev ed from

https://www.hbs.edu/faculty/ Pages/item.a spx?num=3955

Kadir (2015), Statistika Terapan: Konsep, Contoh dan Analisis

Data dengan Program SPSS/ Lisrel dalam Penelitian. PT Raja Grafindo Persada, Ed. 2, Cet. 2, h. 147-148.

Keisidou E., Sarigiannidis L., Maditinos D I. (2015). Customer satisfaction, loyalty and financial performance. International Journal of Bank Marketing

Kotler P., Armstrong, G. (2003) .Dasardasar Pemasaran. Penerbit PT. Indeks Gramedia, Jakarta, Jilid 1, Edisi Kesembilan.
Kumari N., Khanna J. (2017), Cashless Payment: A Behaviourial Change To Economic Growth, International Journal of Scientific Research and Education. Volume 05

Laukkanen, T., \& Lauronen, J. (2005). Consumer value creation in mobile banking services. International Journal of Mobile Communications, 3(4), 325-338. Lupioyadi, R. (2001). Manajemen Pemasaran Jasa : Teori dan Praktek (Service Marketing Management: Theory and Practice). Salemba empat, Jakarta.

Mallat, N. (2007). Exploring Consumer Adoption of Mobile Payments - A Qualitative Study. Helsinki Institute of Economics. Oracle, 2014. Simplicity is the Ultimate Sophistication - The Future of Mobile Payments. U.S.A.: Oracle Financial Services, White Paper.

Micah, Leyira C., EMECA (2016), Cashless policy and profitability of banks in Nigeria, Internaitnal journal of management studies, statistics \& applied economics Vol. 6. Dept Accounting, Faculty of management science Univ of Prot Harcourt.

Olalekan I. \& Araoye (2019), Mobile Banking Advancement Towards Cashless Economy in Nigeria. International Journal of Multidisciplinary and Current Educational Research (IJMCER), Volume 01

Raina, V. K. (2014), Overview of Mobile Payment: Technologies 
and Security, Birla Institute of Technology, India. Journal of Research Gate

Raja, J., Velmurgan, Senthil M. and Seetharaman A. (2008). E-Payments: Problems and Prospects. Malaysia: Journal of Internat Banking and Commerce.

Rangkuti. (2006). Measuring Customer Satisfaction,(Teknik Mengukur dan Strategy Meningkatkan Kepuasan Pelanggan), serta Analisis PLN JP. Jakarta: Gramedia Pustaka Utama.

Reddy, V. (2004). The Present and Future of Electronic Payment Systems. U.S.A.: Santa Clara University, Silicon Valley.

Rusdarti. (2004). Pengaruh Kualitas Pelayanan Dan Nilai Pelayanan Terhadap Loyalitas Nasabah Pada Bank BPD Jawa Tengah Cabang Semarang. Jurnal Bisnis Strategi,Vol. 13, Juli,pp 54-65.

Sekilas mengenai OVO. Retrieved from https://www.cermati.com/emoney/ovo

Siau, K., Sheng, H., Nah, F., \& Davis, S. (2004). A qualitative investigation on consumer trust in mobile commerce. International Journal of Electronic Business, 2(3), 283-300.

Siregar, S. (2013). Statistik Parametrik untuk Penelitian Kuantitatif: Dilengkapi dengan Perhitungan Manual dan Aplikasi SPSS Versi 17. Jakarta: PT Bumi Aksara, Cet. 1.

Sugiyono. (2016). Metode Penelitian Kuantitatif, Kualitatif dan R\&D. Bandung: PT Alfabet.
Shin, D. H. (2009). Towards an understanding of the consumer acceptance of mobile wallet. Computers in Human Behaviour. 25(6), 1343-1354.

Smith, Rodney E., \& Wright, William F. (2004). Determinants of Customer Loyalty and Financial Performance. Journal of Management Accounting Research. Vol.16 pg. 183, 23 pgs

Suliyanto. (2006). Metode Riset Bisnis.Yogyakarta : Andi Offset, pg. 124. Sumarwan, U. (2003). Perilaku Konsumen. Penerbit Ghalia Indonesia, Jakarta

Zeithaml. VA. (1988). Consumer Perceptions of Price, Quality and Value: A Means End Model and Synthesis of Evidence. Journal of Marketing, Vol 52 July.

Zeithaml. VA. Bitner MJ. (1996). Delivering and Performing Service. Part Five. Service Marketing, International Ed. The McGraw-Hill Companies, Inc.

Zulian Y. (2010). Manajemen Kualitas Produk dan Jasa. Yogyakarta:Ekonis 